\title{
石英ガラス光ファイバのエイジングにおける強度低下の予測*
}

\author{
村岡 幹夫*1, 阿 部 博 之*2
}

\section{Prediction of Strength Degradation at Aging of Pristine Silica Optical Fibers}

\author{
Mikio MURAOKA*3 and Hiroyuki ABÉ \\ ${ }^{* 3}$ Department of Mechanical Engineering, Akita University, \\ 1-1 Tegatagakuen-machi, Akita-shi, Akita, 010-8502 Japan
}

\begin{abstract}
Strength degradation of pristine silica optical fibers immersed in water at stress-free condition, i.e., "aging", is believed to result form the roughness development of corroded glass surface. This study has investigated in detail the geometrical properties of the roughness development. Highresolution topography was obtained by atomic force microscopy for aged samples. Simulations of surface roughening were also conducted by means of stochastic differential equation for heterogeneous dissolution of silica. The experiments and simulations suggested that $(1)$ the corroded surface has self-affine geometry, where the Hurst exponent is kept to 0.85 during the roughness development, (2) the roughening is caused by fluctuations of dissolution rate of silica, and (3) the roughness increases in a power law of aging time with an exponent of 0.8 . Boundary element stress analyses for the self-affine surface was also carried out to obtain a relationship between the roughness and the strength, where the surface process layer was introduced to prevent difficulties concerning on stress singularity and the stress concentration factor was adopted as a fracture parameter.
\end{abstract}

Key Words : Corrosion, Fractal, Stress Concentration, Fracture Mechanics, Silica Optical Fiber, Aging, Heterogeneous Dissolution, Self-affine Surface, Fluctuation, Stochastic Differential Equation, Surface Process Layer

\section{1. 緒言}

石英ガラス光ファイバを無応力下で水中に保持した 場合，機械的強度の経時的な低下が生じる. エイジン グと呼ばれるこの現象は，巨視的欠陥を含まないガラ ス表面の不均一腐食による粗さの増加が原因であると いわれている(1). 光ファイバのセンサへの応用では厳 しい環境下での利用もあり，エイジング現象の解明や 予測は工業上も重要である.

現在までに原子間力顕微鏡(AFM)による腐食表面の 観察例 ${ }^{(1)}$ が報告されてはいるが，表面性状の詳細，そ の経時的変化，および，これらと強度低下との関係に ついての十分な検討はなされていない. 本研究では, AFMによる詳細な表面観察および腐食速度のゆらぎ を考慮した腐食のシミュレーションに基づき, 表面粗 さの複雑さに隠れた単純な幾何学的特徵を明らかにす る. さらに, 特異点がき裂の先端に限られる従来の破 壊力学とは異なり, 表面上のすべてが特異点である複 雑表面の力学的取扱いを考察して, エイジングを説明 できるメカニズム（モデル）を提案する.

\section{2. エイジング実験}

* 原稿受付 2003 年 3 月 25 日.

*1 正員, 秋田大学工学資源学部(亚 010-8502 秋田市手形学園 町 1-1).

*2 正員, 東北大学工学部(画980-8579 仙台市青葉区荒巻字 01).

E-mail : muraoka@ipc.akita-u.ac.jp
$2 \cdot 1$ 实験方法 実験にはクラッド径 $125 \mu \mathrm{m}$ の標 準的な石英系光ファイバ素線（アクリル系 UV 硬化型 樹脂被覆，厚さ $62.5 \mu \mathrm{m} ）$ を用いる. ファイバを長さ $100 \mathrm{~mm}$ 程度に切断し，樹脂被覆を通常の工業的手法 (光ファイバ・ストリッパーおよびエタノール払拭)によ り取除いたものと, 樹脂被覆を取除かないものをそれ ぞれ用意し，これを供試材とする. なお，ここで用い る被覆除去の方法(工業的手法)の他に, 熱䈨硫酸等の 溶剤によって被覆を化学的に除去する方法がある.両 者によって得られるガラス表面は, 共に同一の AFM 観察像を与えることが確認されている(1).

次に, ガラスビーカー内の蒸留水 $(\mathrm{pH} 7)$ を温度調節 器によって $90 \pm 3^{\circ} \mathrm{C} に$ 保持し, 多数本の光ファイバ試 験片を水中に設置する. 種々の経過時間で試験片を取 り出し, ファイバのガラス表面を AFMによって観察 する. なお, 観察には先端半径約 $10 \mathrm{~nm}$ の AFM 探針よ るコンタクトモードを採用する. 面内および高さ方向 分解能(解像度)は約 $10 \mathrm{~nm}$ および $0.01 \mathrm{~nm}$ である.

樹脂被覆を取除かない光ファイバについてはエイジ ング後, 水中より取り出し, 先の工業的手法により樹 脂被覆を取除き AFM 観察を行う。ささらに, 試験片の 一部は水中から取り出した後, 樹脂被覆を除去しない 状態で 1 週間以上, 自然乾燥させる.これを用い 2 点 


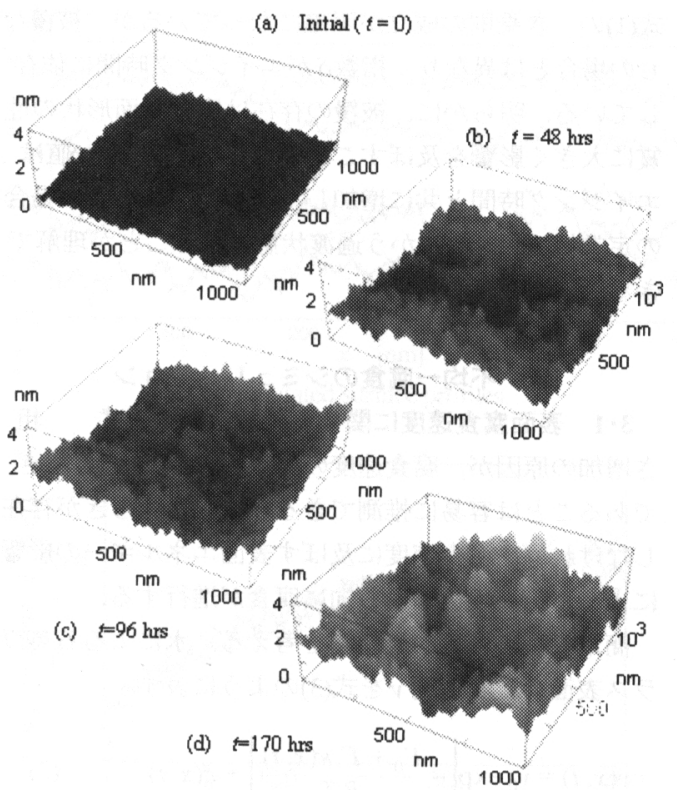

Fig.1 AFM topography of glass surfaces of silica optical fibers aged in distilled water at $90^{\circ} \mathrm{C}$ without resin coating.

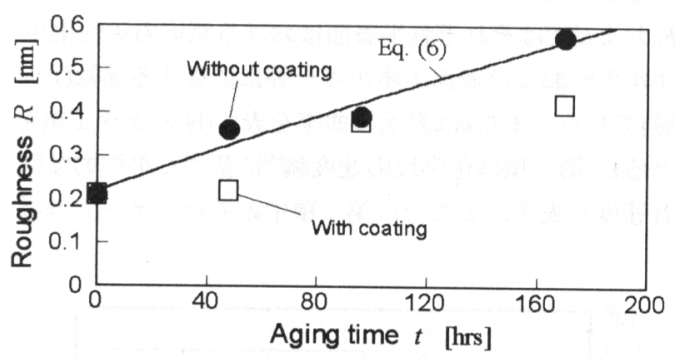

Fig.3 Roughness development.

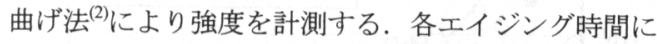
対して 10 本の試験片を用い，負荷速度（2点曲げ間隔 の減少速度） $1 \mathrm{~mm} / \mathrm{s}$ により実験室環境で 2 点曲げ試験 を行う。なお，エイジング実験は最長で約 1600 時間 行う.

$2 \cdot 2$ 実験結果 すべての試験片表面について, き裂や腐食孔等の局在する（明確に定義できる）応力 集中源は観察されず, 複雑な表面粗さが観察された. 図 1 に樹脂被覆を取除いて浸水した光ファイバガラス 表面の AFM 像（走查範囲 $1 \mu \mathrm{m} \times 1 \mu \mathrm{m}$, 画素数 $256 \times$

256）を示す. 図 1 より, エイジング時間 $t$ の経過に従 い, 表面粗さが増していくことがわかる。.また, 初期 表面 $(t=0)$ においても，若干の粗さが存在することが わかる.

図 2 に, 樹脂被覆を取除かずに浸水した光ファイバ

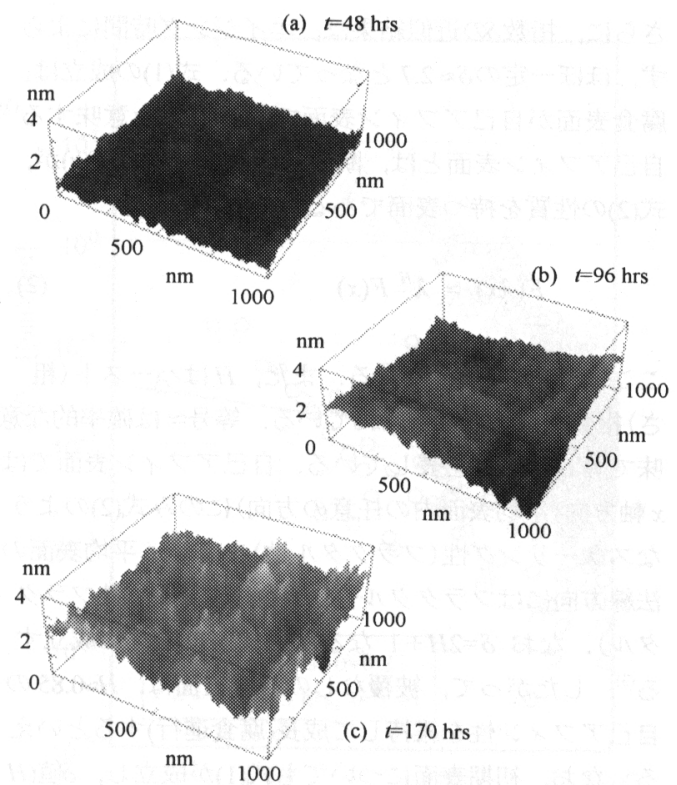

Fig.2 AFM topography of glass surfaces of silica optical fibers aged in distilled water at $90^{\circ} \mathrm{C}$ with resin coating.

ガラス表面の AFM 像（走查範囲 $1 \mu \mathrm{m} \times 1 \mu \mathrm{m}$, 画素数 $256 \times 256$ ) を示す．被覆がない場合(図 1)と異なり，48 時間経過後では, 粗さの大きな増加はみられず, 被覆 効果により腐食が押えられていることがわかる。 しか しながら 96 時間, 170 時間経過後では, 被覆がない場 合(図 1)と同程度の粗さの増加がみられる.なお，実 験前に透明であった樹脂被覆は, 徐々に膨潤し, 白く 変質(軟化)していった. 170 時間経過後では, ストリ ッパーを用いなくてもエタノール払拭のみで十分に被 覆を除去することができる程に，樹脂被覆が軟化して いた. 図 3 は, 図 1,2 をもとに, 表面粗さ $R$ (二乗平 均）を求め, エイジング時間 $(t)$ との関係を整理した結 果である.

図 4 に, 初期および樹脂被覆を取除いた場合のエイ ジング表面形状（図 1)に基づく空間パワースペクトル 密度 $S(f)$ を示す.ここに $f$ は空間周波数である. 図 4 中 の各記号は図 1 の各エイジング時間に対応した形状画 像から, それぞれ走查方向断面の 1 例を用いて, 周波 数解析した結果である. また直線は式(1)のべき乗則 を用いて最小二乗近似した結果である. 相関係数の二 乗は 0.85 ０.9 となっており，表面のパワースペクト 儿密度が式(1)を用いて近似できることがわかる。

$$
S(f) \propto f^{-\delta}
$$




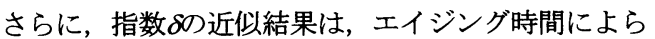
ず，ほぼ一定の $\delta \approx 2.7$ となっている. 式(1)の成立は, 腐食表面が自己アフィン表面であることを意味する ${ }^{(3)}$. 自己アフィン表面とは，断面形状を表す関数 $F(x)$ が， 式(2)の性質を持つ表面である ${ }^{(3)}$.

$$
F(\lambda x) \simeq \lambda^{H} F(x)
$$

ここに入は尺度因子である．また，Hはハースト(粗 さ)指数 $(0<H<1)$ と呼ばれている. 等号〜は確率的な意 味で等しいことを表している．自己アフィン表面では $x$ 軸方向 (平均表面内の任意の方向)にのみ式(2)のよう なスケーリング性(フラクタル性)を有し, 平均表面の 法線方向にはフラクタル性を持たない(異方性フラク タル). なお $\delta=2 H+1$ なる関係式が理論的に成立す る(3). したがって, 被覆なしの腐食表面は, $H \approx 0.85$ の 自己アフィン性を維持して成長(腐食進行)するといえ る. なお, 初期表面についても式(1)が成立し, $\delta$ 值 $(H$ 值)が腐食進行後の值と等しいという結果に関しては, $4 \cdot 1$ 節で考察する.

図 5 は, 被覆がある場合のエイジング表面(図 2)に 基づき， $S(f)$ を求めた結果である. 記号や直線の求め 方は図 4 の場合と同様である. 式(1)の近似における相 関係数の二乗は, $t=48 \mathrm{hrs}$ の場合に 0.77 となり, 近似度 が悪い. しかしながら, 他の場合は 0.9 となり近似は 良好である.このようにエイジング時間の経過に従い，

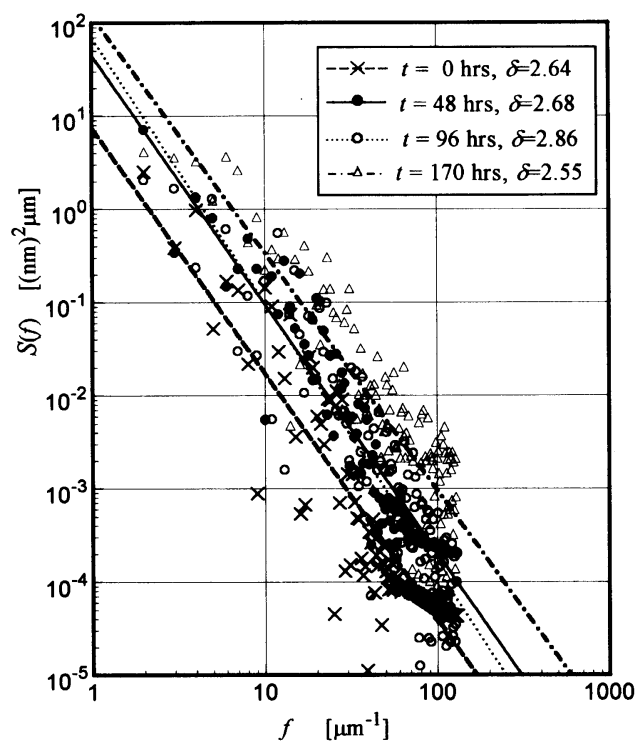

Fig.4 Spectra of corroded surface of bare silica optical fibers.
式(1)のべき乗則の成立が明確になっているが，被覆な

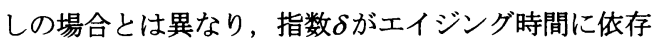
している，明らかに，被覆の存在は腐食表面形状の性 質に大きく影響を及ぼすことがわかる．また， 植は エイジング時間と共に増加しており，被覆なしの場合 の定常值 $\delta \approx 2.7$ に向かう過渡状態にあることが理解で きる。

\section{3. 不均一度食のシミュレーション}

3.1 表面席食速度に関する確率微分方程式 粗 さ増加の原因が，腐食速度の場所的・時間的なゆらぎ であることは容易に推測できる．もし，ゆらぎが存在 しなければ，腐食速度に及ぼす表面エネルギーの影響 によって，平坦化する方向に腐食が進行する.

簡単のために二次元問題を考える. 水による石英カ ラス表面の腐食速度 $v$ を式(3)のように表す.

$$
v(x, t)=v_{0} \exp \left[-\frac{E_{0}+\Gamma \kappa(x, t)}{R T}\right]+\xi(x, t)
$$

ここに $R(=8.314 \mathrm{~J} / \mathrm{mol} / \mathrm{K}), T$ および $v_{0}$ は，それぞれガ 不定数, 絶対温度および活量に依存する係数である.

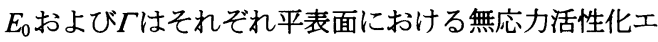
ネルギーおよび表面エネルギー等に依存する係数(正 值)である．またネ表面の曲率を表す(凹のとき正值を とる). 第一項は化学反応速度論 ${ }^{(4)}$ に基づく平均的な腐 食速度を表す.ここでは第一項中の各パラメータの場

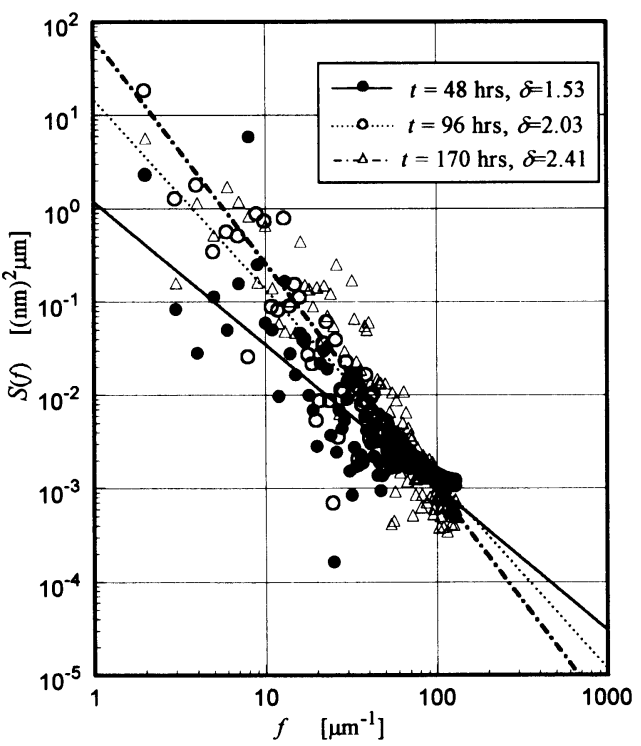

Fig.5 Spectra of corroded glass surface of resin-coated silica optical fibers. 


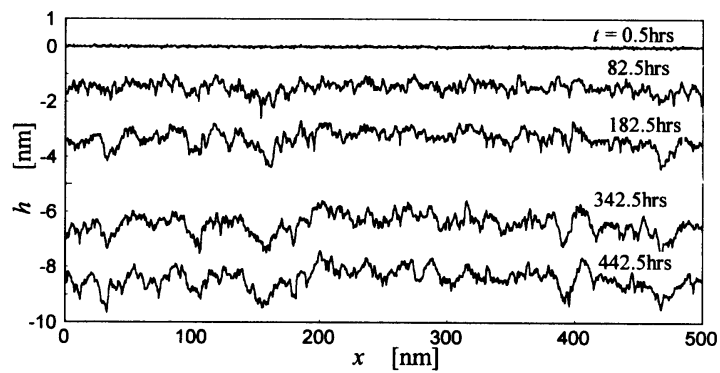

Fig.6 Simulated surface profiles.

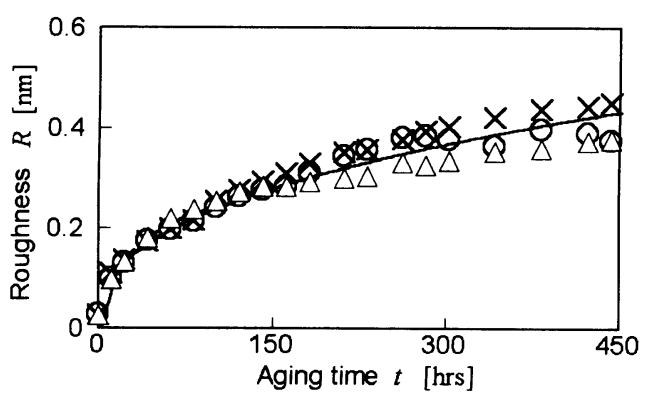

Fig.7 Simulated roughness development.

所的・時間的ゆらぎが微小量であることを仮定し，こ れらの影響を第二項のゆらぎ項（ウィナー過程に従う 変数) で代表させている.

表面の高さを $h$ (初期表面 $h=0)$ とすれば, 微小時間 $\Delta t$ 経過後の高さの减少量 $-\Delta h$ は, 式(3)をもとにした次 の確率微分方程式により表現できる.

$-\Delta h=v_{\text {flat }} \exp \left[-\frac{\Gamma \kappa(x, t)}{R T}\right] \frac{\Delta t}{\cos [\theta(x, t)]}+\eta(x, t) \sqrt{\Delta t}$

ここに， $v_{\text {flat }}$ は平表面 $(\kappa=0)$ の平均腐食速度である. 式 (4)の右辺第一項は, 式(3)が表面の法線方向の腐食速度 であることを考虑し，これを傾斜角 $\theta(x, t)$ の表面に対し て補正している. 第二項は, 確率微分方程式の理論に 基づいている(5). このようにゆらぎの影響は $\sqrt{\Delta t}$ に比 例する. $\eta(x, t)$ は正規分布(平均值 0 , 標準偏差が $S D$ )の 乱数である.

$3 \cdot 2$ 不均一底食のシミュレーション 長さ $L$ の 区間を対象とし，また $x$ 方向に周期境界条件を適用す る. 同区間を $n$ 等分し, 式(4)を用いて各格子点の高さ 方向の腐食量を計算する. このとき表面の曲率および 法線の方向余弦については，隣接する格子点の高さを 用いて差分により近似する. また, 各格子点で正規分 布の乱数を逐次発生させ, これを $\eta(x, t)$ の值とする. なお, 粗さの増加に伴い, 曲率( $($ ) $)$ が大きくなるが, そ の上限を $1 / \rho_{\mathrm{C}}$ とする(6). ここに $\rho_{\mathrm{C}}$ は材料の特性寸法で

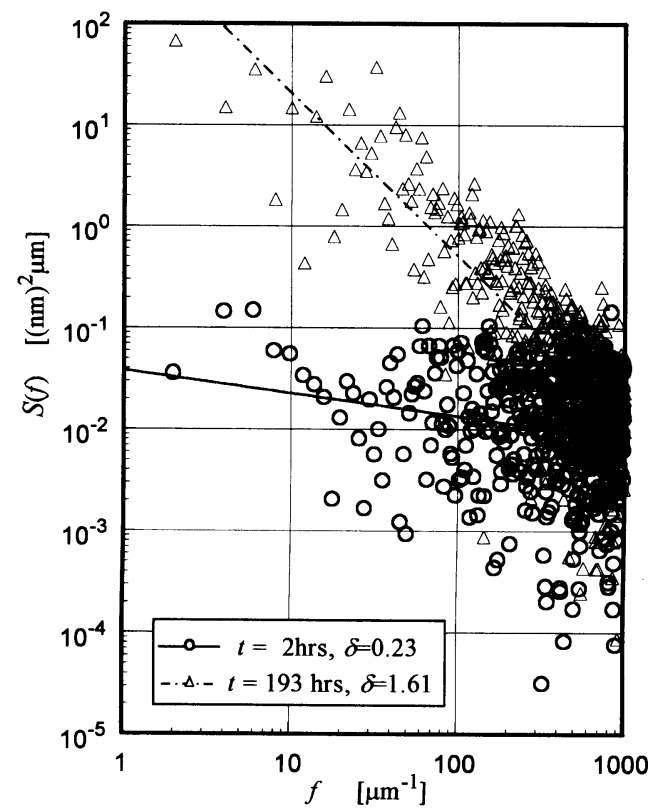

Fig. 8 Spectra of simulated surface profiles.

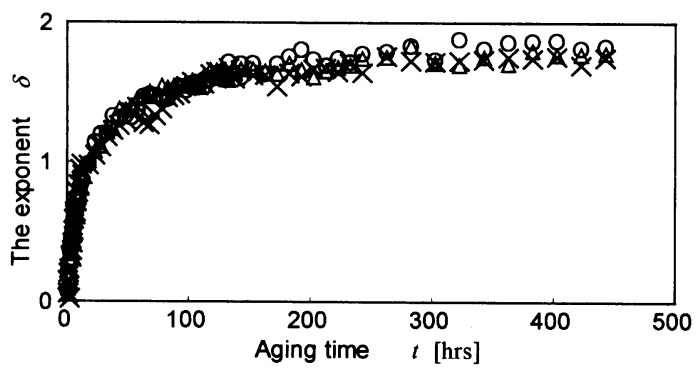

Fig. 9 The exponent $\delta$ of spectra versus aging time for simulations.

あり, 石英ガラスの無規則網目構造における穴の半径 $\rho_{\mathrm{C}}=0.5 \mathrm{~nm}$ を採用する.

シミュレーションでは, 2 章のエイジング実験と同様 に $90^{\circ} \mathrm{C}$ 水中のエイジングを対象とする. このとき平表面 $(\kappa=0)$ における腐食速度は, 村岡らの計測結果 $\left(v_{0}=1.17 \mathrm{~m} / \mathrm{s}\right.$, $\left.E_{0}=109 \mathrm{~kJ} / \mathrm{mol}\right)^{(6)}$ より定める $\left(v_{\text {flat }}=4.15 \times 10^{-15} \mathrm{~m} / \mathrm{s}\right)$. また, $\Gamma=3$ を用いる(の). さらに, $L=500 \mathrm{~nm}, n=1000$ および $\Delta=900 \mathrm{~s}$ を用いる. ゆらぎの強さ，すなわち $\eta(x, t)$ の標準偏差 $(S D)$ は, シミュレーションにより得られる表面の粗さが, 2 章の観察結果と同程度となるように定める. 本研究 では,SD $=5.6 \times 10^{-8} \mathrm{~mm} / \mathrm{s}^{1 / 2}$ を採用する. 以上の条件のも と, 約 440 時間程度までのエイジングシミュレーショ ンを3回行う. 
$3 \cdot 3$ シミュレーション結果 図6に本シミュレ ーションより得られた表面形状の経時的変化の一例を 示す. 図6は，二次元問題を対象とした結果ではある が，十分に腐食が進行した時点では，実験で観察され る断面形状に類似している. 図 7 は, 本シミュレーシ ヨンより得られた表面形状をもとに粗さ $R$ を求め, そ の時間変化を整理したものである. なお，同一条件下

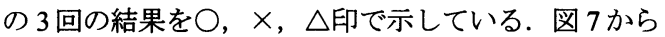
次の関係が成立していることがわかる.

$$
R \propto t^{\beta} \propto \bar{d}^{\beta}
$$

ここに $\bar{d}(=-\bar{h})$ は平均腐食深さであり，エイジング時 間 $t$ に比例する. なお, 図 7 より最小二乗近似結果と して $\beta=0.4$ を得る. また, 本問題の対象である腐食と は異なるが，イーデンモデルなどの析出の表面成長シ ミュレーションにおいても式(5)と同様の結果が確認さ れている(3).

図 8 に,シミュレーションにより得られた腐食表 面の空間パワースペクトル密度 $S(f)$ と空間周波数 $f$ の関係を示す. $t=193 \mathrm{hrs}$ のシミュレーション結果か らわかるように，実験結果と同様に式(1)に示した べき乗則が成立している，なお， $>20 \mathrm{hrs}$ の範囲で あれば $t=193 \mathrm{hrs}$ の場合と同程度に式(1)が成立するこ とを確認している。図 9 は, 図 8 中の実線のように 最小二乗近似により $\delta$ 值を求め, $\delta$ とエイジング時 間 $\boldsymbol{t}$ の関係を整理した結果である（3回のシミュレ

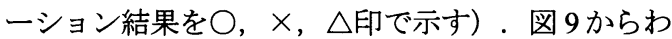
かるように，初期の段階では，腐食表面は過渡状態 にあり,そのため值は変化するが, やがて一定值 $(\delta=1.8)$ に近づいていく，十分に成長した腐食表面 は，植が一定すなわちハースト指数 $(H)$ が一定の状 態で成長を続けるといえる.このことは，実験結果 (図 4)と一致する. なお， $(\delta=1.8)$ と実験 $(\delta=2.7)$ において互いに異なる理由は, 空間次元の相違によるものであると推測できる.

\section{4. エイジング予測モデル}

4.1 表面粗さの経時変化 本章では, 2 章の表面 観察結果および3 章の表面腐食シミュレーション結果 に基づき，エイジングによる強度低下のメカニズムに ついて検討する. これに先立ち, 本節では, 図 3 に示 した表面粗さの経時変化の観察結果について考察する. 前述のように初期 $(t=0)$ においても粗さが存在する.こ れは, 光ファイバが $2000^{\circ} \mathrm{C}$ 加熱し軟化したガラス母 材を線引きして製造されることを考えると不自然では ない. 固化前の熱的ゆらぎによって，必然的に表面に
は粗さが生じる. しかしながら，観察された初期表面 のスペクトル指数放，十分に発達した不均一腐食表 面特有の值 $(\delta \approx 2.7)$ にほぼ等しいことから，製造時の熱 的ゆらぎによって生じた粗さとは考え難い.むしろ AFM 観察時の被覆除去直後に次のような腐食が生じ たと考える方が自然である. 被覆除去後, 光ファイバ のガラス表面は実験室の大気にさらされ, 大気中の湿 気により水の吸着膜で覆われる. 被覆除去前のガラス は，樹脂被覆によって， $\mathrm{OH}$ 基の少ない比較的新鮮な 表面となっている(製造時の線引き工程で, 固化後直 ちに樹脂被覆が施されている). そのため被覆除去に よる水の吸着膜形成と同時にその新鮮なガラス表面は, 水との化学反応により急速に腐食されるはずである. また, 水膜の厚さは, 通常の湿度では数 $\mathrm{nm}$ 程度なの で，生成物が膜中で飽和し，腐食は停止すると考えら れる.

ここで図 3○印(被覆なしのエイジング)に注目する. シミュレーションによれば, 粗さの発達は式(5)のべき

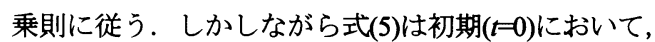
粗さが存在しない場合の結果であるので，式(5)を式(6) のように補正し，これを図 3○印にあてはめてみる.

$$
R=k_{\mathrm{R}}\left(t+t_{0}\right)^{\beta}
$$

ここに $k_{\mathrm{R}} \beta, t_{0}$ は近似パラメータである. 図 3 中の実 線は, 式(6)を用いた非線形最小二乗近似結果 $(\beta=0.80$, $\left.t_{0}=74[\mathrm{hrs}]\right)$ である. 実験結果は, 式(6)に従っているよう にみえる。

被覆がある場合(図 3ロ印)では, エイジング開始後, 少なくとも 50 時間程度は被覆の効果があり, 粗さの 増加が押えられているが，やがてその効果は低下し， 裸の場合と同様に図 3 の実線に沿って粗さが成長する と考えられる.

\section{$4 \cdot 2$ 定常席食表面の応力解析被覆がある場合} でも，エイジング時間が十分経過すれば，被覆がない 場合と同様に，式(6)のように時間のべき乗に比例して 粗さが増加する. また, 十分に発達した腐食表面は, 值が一定の自己アフィン性を維持して成長する.こ のような腐食進行中の表面を, 以降, 定常腐食表面と 呼ぶ.

ここでは，定常腐食表面を有する場合の強度につい て検討する．同表面は，自己アフィン性という比較的 単純な幾何学的性質を有しているが, その形状は応力 解析を行う上では極めて複雑である. 本研究では,こ のような表面上のすべてが特異点である複雑な表面の 応力に注目する，また简単のため, 連続体弾性理論を 


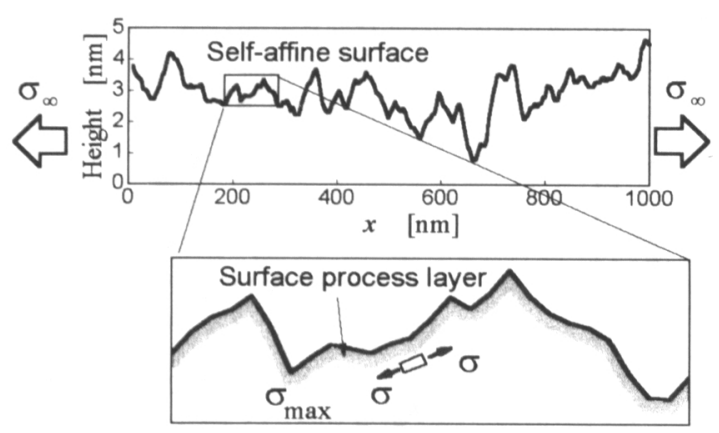

Fig.10 Cross section of a corroded surface [after Fig.1 (d)] and explanation of surface process layer.

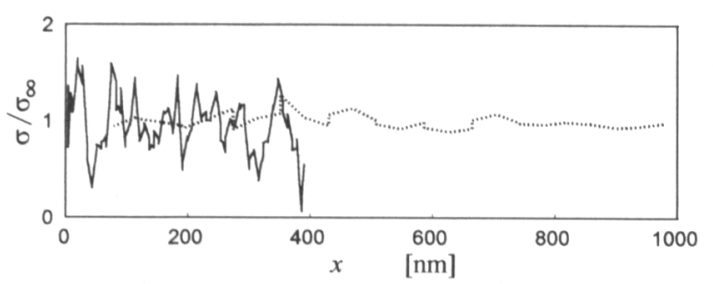

Fig.11 Principal stress distribution along the surface

用いる. 光ファイバ用石英ガラスは，表面原子のみが $\mathrm{OH}$ 基を形成するという化学的修飾を受けるが, 内部 は表面の極近傍に至るまで均質高純度である，表面の 数原子層では, 連続体力学は適用できないが, き裂の 力学におけるプロセスゾーンとこれを囲む応力拡大係 数支配領域のように，表面の数原子層をプロセスゾー ン（表面プロセス層）と考え，それを覆う下層部の応 力集中を考える(図 10 参照). また，石英ガラスは引張 に対して塑性のような永久変形は生じない。このこと からも表面形状による応力集中に注目し, 強度を議論 することは妥当であるといえる.

なお, ガラスの強度は, 通常き裂を想定した応力拡 大係数に基づき評価されるが，ここではあえて応力集 中により強度を議論する.この理由について若干の補 足をする. 無損傷光ファイバの不活性強度(12GPa 以 上)は，石英ガラスの理論強度の約 $1 / 2$ 以上の大きさを 持つ ${ }^{(6)}$. また, 石英ガラスの破壊勒性値 $(0.8 \mathrm{MPa} \sqrt{\mathrm{m}})^{(7)}$ と上記の不活性強度を用いて, 等価き裂寸法を見積も れば，約 $3 \mathrm{~nm}$ 以下となる．これは石英ガラス $\mathrm{Si}-\mathrm{O}$ 網 目構造の穴寸法の約 6 倍以下であり，このようなき裂 が存在したとしても, もはや連続体力学の応力桩大係 数は適用できないであろう。また AFM 観察によれば 腐食孔のような局在した応力集中源も確認されていな い. したがって自己アフィン表面の応力集中を直接

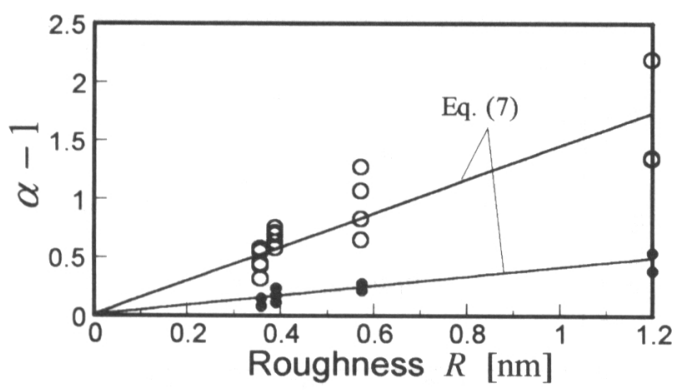

Fig.12 Relationship between stress concentrate factor $\alpha$ and roughness $R$ for $2 \mathrm{D}$ self-affine profiles.

評価することが, 最も自然であると思われる。

さて, 定常腐食表面は自己アフィン性を示し, 同一 の表面構造を維持して成長する（ $\delta$ あるいは $H$ が一 定）.したがって, 腐食進行に伴う定常腐食表面の応 力集中係数 $\alpha$ の変化は, 粗さ $R$ の寄与によると考える

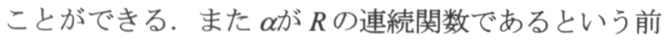
提に基づき， $\alpha$ を $R=0$ においてテイラー級数展開する. さらに $R$ が微小であることより, $\alpha$ と $R$ の関係は, 式 (7)のように $R$ の一次式により近似できる.

$$
\alpha=1+k_{\mathrm{S}}(\delta, B) R
$$

ここに $k_{\mathrm{S}}(\delta, B)$ は $\delta$ と空間周波数の帯域幅 $B$ に依存する 係数である.

本研究では, 式(7)の妥当性を調べるため, 自己アフ イン表面を有する半無限弾性体の表面上の応力分布を 境界要素法により近似的に解析した. その際, 簡単の ため二次元問題を対象とし，周期境界条件が適用でき る境界要素応力解析コードを新たに作成した. 図 10 は, AFM 観察による断面形状の一例[図 1(d)]である. 応力解析では, このような実際の断面形状を有する仮 想的な二次元無限弾性体を計算対象とした. また, 計 算の都合上, 境界要素(二次要素)の総節点数は最大で 100 個である. 図 10 のような形状データから連続で 100 個選んだもの（要素長 $7.8 \mathrm{~nm}$ ）と，10 個おきに 25 個選んだもの(要素長 $78.4 \mathrm{~nm}$ )を節点とした。この境界 要素モデルの全長はそれぞれ $391 \mathrm{~nm}$ と $977 \mathrm{~nm}$ である. この全長を基本区間とし周期境界条件を適用して, 無 限表面を近似した. 外応力としては, 光ファイバの引 張を考慮し, 無限遠方において平均表面に平行に垂直 応力 $\sigma_{\infty}$ をえた.

図 11 に, 一例として図 10 の形状に対する表面上の 主応力分布を示す. 実線および点線は要素長がそれぞ れ 7.8nm および 78.4nm の場合の結果である. なお, 


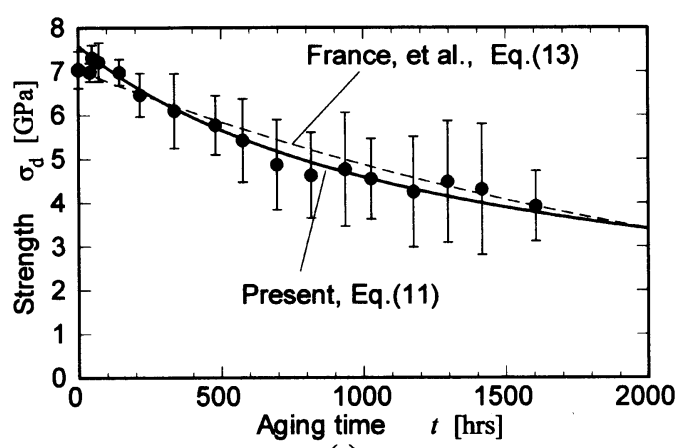

(a)

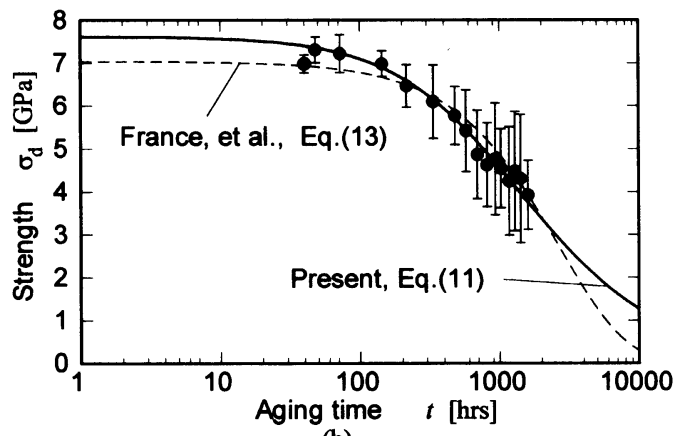

(b)

Fig.13 Fitting to data of strength degradation.

主応力 $\sigma$ は $\sigma_{\infty} に よ り$ 正規化している. このような応力 解析結果により, 最大局所応力 $\sigma_{\max }$ を求め, 応力集中 係数 $\alpha\left(=\sigma_{\max } / \sigma_{\infty}\right)$ を求める. 以上と同様にして, 図 1 の AFM 観察形状をもとに, $\alpha$ と $R$ の関係を求めた結果を 図 12 に示す. ○印および○印は要素長がそれぞれ $7.8 \mathrm{~nm}$ および 78.4nm の場合の結果である. なお， $R$ $=1.2 \mathrm{~nm}$ におけるデータは, 図 1(d)の断面形状（R $=0.6 \mathrm{~nm}$ ）を高さ方向に 2 倍して作成した形状を使用し て求めている. なお, 高さ方向に 2 倍に拡大しても, そのハースト指数 $(H)$ の值は変化しない. 図 12 からわ かるように, 式(7)は要素分割の細かさによらず近似的 に成立している．また要素分割の細かさは $\alpha-1$ と $R$ の 関係の比例係数（傾き）にのみ影響している. 応力解 析では要素長よりも小さい波長の表面形状成分はカッ トされる. 計算結果に及ぼす要素分割の細かさの影響 は, 応力集中係数に及ぼす周波数帯域幅 $B$ の影響と等 価であると考えられる. したがって, 式(7)の係数 $k_{\mathrm{s}}$ が $B$ にも依存することは妥当であるといえる. なお， $B$ が大きい表面ほど, 細かい凹凸を含むため, 応力集中 係数が大きくなる. しがたって $k_{\mathrm{S}}$ は $B$ の単調増加関数 であると考えられる.

以上のことから，原子分解能で十分広い範囲を観察 し十分に細かい要素分割により忠実にモデル化した理 想的な場合においても，Bが大きくなるのみであるか ら, 先と同様に $\alpha-1$ と $R$ の比例関係が近似的に成立す る. すなわち実際の表面に対する係数 $k_{\mathrm{S}}$ の正確な值を 求めるのは困難であるが，式(7)の関係は近似的に成立 する.

4·3 エイジング予測式 式(6)および式(7)から, 定常腐食表面の応力集中係数の経時変化は次のように 表される.

$$
\alpha=k\left(t+t_{0}\right)^{\beta}+1
$$

ここに $k$ は, 式(6)と式(7)の比例係数の積 $\left(k=k_{\mathrm{R}} k_{\mathrm{S}}\right)$ である. 式(6)の比例係数 $\left(k_{\mathrm{R}}\right)$ が温度に依存することが容易に 推測できるので, $k$ 值も温度に依存すると考えられる. また, $\beta$ 值は, フラクタル成長理論からの予測や， 3 章 のシミュレーションにおいて無次元化が可能であった ことから, 水中における石英ガラスの定常腐食表面で は温度によらず( $v_{\text {flat }}$ によらず)一定值(図 3 の近似結果 $\beta=0.8)$ をとると考えられる.

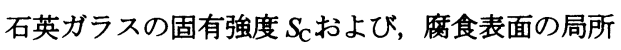
最大応力 $\sigma_{\max }$ を用いて, 破断条件を次のように表す.

$$
\sigma_{\max } \geq S_{\mathrm{C}}
$$

このとき応力集中係数 $は$ は, その定義より, 固有強度 と光ファイバの引張強度 $\sigma_{\mathrm{d}}$ の比に等しい.

$$
\alpha=\frac{\sigma_{\max }}{\sigma_{\infty}}=\frac{S_{\mathrm{C}}}{\sigma_{\mathrm{d}}}
$$

式(8)および式(10)より， $\sigma_{\mathrm{d}}$ の経時変化を次のように表 すことができる.

$$
\sigma_{\mathrm{d}}=\frac{S_{\mathrm{C}}}{k\left(t+t_{0}\right)^{\beta}+1}
$$

式(11)は定常腐食表面の場合に有効である.

図 13 の○印は, 樹脂被覆がある場合のエイジング による強度低下の計測結果（二点曲げ試験により計測 した結果) である. 誤差線は標準偏差の 2 倍の区間

（確率 95.4\%の信頼区間）を表す．図 13 からわかるよ うに, エイジング開始から約 150 時間までは, 初期 強度を維持するが, その後, 緩やかな強度低下が生じ る.この強度低下は，AFM 観察結果から推測できる ように，被覆の膨潤・軟化変質により耐水効果が無く なったためによる. そこで, 約 150 時間以降では定常 腐食表面になっていると考え, 約 150 時間以降のデー 
夕を用いて，式(11)により非線形最小二乗近似を行っ た（図 13 実線）。その際，固有強度 $\left(S_{\mathrm{C}}\right)$ として理論強 度值 20GPa を用いた。近似パラメータは, $t_{0}$ および $k$

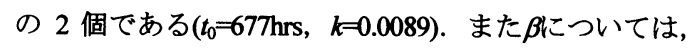
先の議論のように AFM 観察結果（粗さの成長）に基 ぶく値( $\beta=0.8)$ を用いた. なお， $S_{\mathrm{C}}=40 \mathrm{GPa}$ を用いた場合 においても, 同様の近似曲線が得られ, 図 13 中の寒 線と重なってしまう。.このように近似曲線は $S_{\mathrm{C}}$ の值 に鈍感である. そこで式(11)を次のように近似する.

$$
\sigma_{\mathrm{d}}=\frac{S_{\mathrm{e}}}{\left(t+t_{0}\right)^{\beta}}
$$

ここに, $t_{0}, S_{\mathrm{c}}$ は近似パラメータである. また $\beta=0.8$ である. 式(12)による近似結果も, 図 13 の実線と重な る.

Franceらは, エイジングによる強度低下に関し，式 (12) と類似の式(13)を現象論的な経験式として提案して いる(8).

$$
\sigma_{\mathrm{d}}=\frac{\sigma_{\mathrm{d} 0}}{(1+a t)^{b}}
$$

ここに $\sigma_{\mathrm{d} 0}$ は初期強度である. Franceらの経験式では, 本研究の場合 ( $\beta$ は既定值 0.8 をとる) とは異なり, 指数 $b$ も近似パラメータとして用いられる. また初期 值として初期強度をとり, 過渡状態のデータも近似に 用いられる. France らの経験式に基づく非線形最小二 乗近似結果（図 13 中の破線, $\sigma_{00}=7.04 \mathrm{GPa}$, 近似パラメ 一夕 $a=1.12 \times 10^{-8} \mathrm{~s}^{-1}, b=9.31$, 相関係数の 2 乗 $r^{2}=$

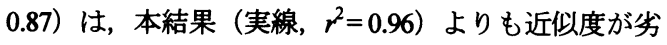
る. また, 片対数表示した図 13(b)からわかるように, 本研究の予測との差は, 時間の経過に伴い大きくなっ ていく. 本予測方法は表面腐食形状の成長メカニズム に立脚しているという物理的根拠を有しているため, France らの現象理論的予測よりも信頼性があるといえ る.

\section{5. 結}

石英ガラス光ファイバの $90^{\circ} \mathrm{C}$ 水中におけるエイジン グ試験（無応力下での浸水試験）を行い，種々の経過 時間における腐食表面を原子間力顕微鏡により観察し
た.これにより，腐食表面は，一見複雑ではあるが， 十分に発達すれば, ハースト指数 0.85 の自己アフィン 性（一種のフラクタル性）を維持して成長する（進行 する）ことが明らかとなった。

また，腐食速度のゆらぎを考虑した確率微分方程式 に基づき, 表面形状の経時変化のシミュレーションを 行った. その結果, 一定の自己アフィン性を維持して 腐食表面が成長するという実験事実が，同シミュレー ションにおいても再現されることがわかり，腐食速度 のゆらぎが本現象の主要因である根拠を得た．さらに， 表面粗さは，時間のべき乗に比例して増加することが わかった.

以上の結果を踏まえ, さらに, 破壞プロセスが実 際に起こる表面プロセス層を考え，これを支配する下 地の応力集中に注目して, 自己アフィン表面（腐食表 面）の強度評価を行った. 周期境界条件が適用できる 境界要素応力解析コードを作成し，腐食表面形状の観 察結果に基づき表面に沿った応力分布を調べた. その 結果, 腐食表面の応力集中係数から 1 を减じた量は表 面粗さに比例することがわかった. このような，き裂 の力学ではなく, 自己アフィン表面の力学とも呼べる 破壊力学によって, エイジングによる経時的強度低下 の予測手法を考案した.

\section{考文献}

(1) Rondinella, V. V., Matthewson, M. J. and Kurkjian, C. R., J. Am. Ceram. Soc., 77-1 (1994), 73-80.

(2) Muraoka, M., Trans. ASME, J. Elect. Pack., 123-1 (2001), 70-73.

(3) タマスヴィチェック (宮島佐介訳), フラクタル成長 現象, (1990), 146-167, 朝倉書店.

(4) Wiederhorn, S. M., Fuller Jr., E. R. and Thomson, R., Metal Sci., (1980-8,9), 450-458.

(5) 長井英生, 確率微分方程式, (1999), 100, 共立出版.

(6)村岡幹夫・阿部博之, 機論, 65-629, A (1999), 113-119.

(7) 村岡幹夫 • 阿部博之, 機論, 55-512, A (1989), 798-802.

(8) France, P. W., Duncan, W. J., Smith, D. J. and Beales, K. J., J. Mater. Sci., 18 (1983), 785-792. 